\title{
CÂTEVA OBSERVATTII ASUPRA MODULUI ÎN CARE SE REFLECTĂ DUNĂREA ÎN MENTALUL LOCUITORILOR EI \\ Un studiu de caz românesc: Dunărea de Jos, Orașul Giurgiu/
}

SOME OBSERVATIONS ON HOW DANUBE IS REFLECTED IN THE MINDS OF ITS INHABITANTS

\author{
A Romanian Case Study: Lower Danube, Giurgiu City
}

Angelica STAN, habil. conf. dr. arh./ assoc. prof. PhD. arch.

angelica.stan@gmail.com

Universitatea de Arhitectură şi Urbanism „Ion Mincu”, Bucureşti, RO/

„Ion Mincu” University of Architecture and Urbanism, Bucharest, RO

\section{Rezumat}

Cum se reflectă Dunărea în mentalitatea actuală a locuitorilor săi, dincolo de stereotipuri și percepții învechite? În contextul unei abordări diferențiate a Dunării - datorat diversității culturale și etnice a țărilor dunărene atât la nivel macro-teritorial, cât și la un nivel micro-teritorial, ultra-local - lucrarea noastră investighează asupra unei modalități neconvenționale de a capta percepția colectivă a locuitorilor unui oraș mic pe Dunăre (fără a apela la studii sociologice de amploare).

Luând în considerare acest aspect al specificității percepției fluviului Dunărea pe tot parcursul ei, aplicând ipoteza respectivă pe orașul Giurgiu ca studiu de caz pentru regiunea Dunării de Jos în

\begin{abstract}
How is Danube reflected by the current mentality of its inhabitants, beyond stereotypes and obsolete perceptions? In the context of a differentiated approach of Danube as matrix of a social, cultural and ethnic diversity, both at a macro-territorial level, and at a micro-scale, ultra-local level - this paper investigates an unconventional way (not by using extensive sociological studies) of capturing the inhabitants' collectiv perception of Danube.
\end{abstract}

Considering this aspect of the specificity of Danube's perception throughout it, applying it to the city of Giurgiu as a case study for the region of the Lower Danube in Romania, we tested an atypical 
România, am testat un chestionar atipic și o metodă de investigare bazate pe reprezentarea directă și pe recunoașterea tiparelor spațiale și culturale.

Dincolo de etichetele urbane sau rurale (care nu sunt destul de exacte pentru a descrie aceste teritorii în România, deoarece această graniță este foarte vagă), Dunărea este percepută nu numai ca spațiu fizic, ci și ca "interior viu", mental, văzut cu vederea "periferică" - cea care nu se focalizează direct pe obiecte, dar "înregistrează" instantaneu toate datele unei realități complexe. Această realitate include nu numai forma spațiului construit al Dunării, peisajul și funcțiile/activitățile sale, ci și ambianțele și chiar sentimentele asociate sau generate de structurile fizice.

Rezultatul cercetării verifică necesitatea de a înțelege mai bine Dunărea atât ca purtătoare a unui specific local al locuirii (cu valențe tradiționaliste), dar și ca matrice cu valențe de universalitate, ca manifestare a unor dorințe de inovație sau de corelare cu alte modele. "Mentalul" locuirii la Dunăre este alcătuit atât din elemente ce privesc percepția imediată și intens personalizată din viața cotidiană a oamenilor, cât și imagini sau date care se adresează memoriei, imaginației sau educației legate de Dunăre.

Scopul principal a fost acela de a găsi caracterul specific și principalii indicatori ai "imaginii mentale" a Dunării pentru locuitorii actuali ai orașului Giurgiu, și totodată de a pregăti un model de cercetare a acestui aspect ca extrapolare pentru intregul teritoriul al Dunării. Am realizat această lucrare ca activitate de cercetare în cadrul proiectului DANUrB (http://www.interreg-danube.eu/approvedprojects/danurb), în completarea altor studii asociate, de ex. studiul valorilor "ascunse" de questionnaire and a method of investigation based on direct representation and recognition of spatial language and cultural patterns.

Beyond the urban or rural labels (which are not quite accurate, but assumed by inhabitants by some inertial thinking) the Danube is perceived not only as a physical space, but also as a "living interior", mentally seen with the "peripheral" view - the one that does not focus directly on objects, but "instantly" records all the data of a complex reality. This reality includes not only the built-up shape of the Danube, its landscape and/or its functions/activities, but also its surroundings and even the associated feelings or generated by physical structures.

The result of the research examines the need to better understand the Danube as a carrier of a local specificity of habitation, with traditionalist/ inertial valences, but also as a matrix with universal qualities, as a manifestation of a general desire for innovation or correlation with other models. The "mental" of living on the Danube is made up of both elements that concern the immediate and intensely personalized perception of people's daily lives, as well as images or data that address memory, imagination or education related to the Danube.

The main purpose was to find the specific character and main indicators of the "mental image" of the Danube for the current inhabitants of Giurgiu, and at the same time to prepare a future research model of this aspect, as extrapolation for a larger territory of Danube. I performed this work as a research activity within the DANUrB project (http://www.interreg-danube.eu/approvedprojects/danurb), in addition to other associated studies, eg. the study of the "hidden" values of local 
patrimoniu local, studiul asupra potențialului turistic, sau al peisajul sonor al orașului în raport cu Dunărea.

\section{Cuvinte cheie/ Keywords}

mentalitate, locuitori, Dunăre, limbaj/

mentality, inhabitants, Danube, language

\section{Obiectivele și instrumentele cercetării}

Obiectivul central al lucrării este de a investiga, printr-o luare de poziție personalizată, felul în care se reflectă Dunărea în mentalitatea actuală a locuitorilor săi, în contextul unei abordări diferențiate a Dunării asociată diversității culturale și etnice a țărilor dunărene.

Luând în considerare acest aspect al specificității percepției fluviului Dunărea pe tot parcursul ei, aplicând apoi ipoteza respectivă pe orașul Giurgiu, ca studiu de caz pentru regiunea Dunării de Jos în România, am testat un chestionar atipic și o metodă de investigare bazate pe reprezentarea directă și pe recunoașterea tiparelor spațiale și culturale. Dincolo de etichetele urbane sau rurale (care nu sunt destul de exacte pentru a descrie aceste teritorii în România, deoarece această graniță este foarte vagă), Dunărea este percepută nu numai ca spațiu fizic, ci și ca "interior viu", mental, văzut cu vederea "periferică" - cea care nu se focalizează direct pe obiecte, dar "înregistrează" instantaneu toate datele unei realități complexe. Această realitate include nu numai forma spațiului construit al Dunării, peisajul și funcțiile / activitățile sale, ci și ambianțele și chiar sentimentele asociate sau generate de structurile fizice. heritage, the study of the tourist potential, or the sound landscape of the city in relation to the Danube.

\section{The research objectives and tools}

The central objective of the paper is to investigate, through a personalized position, how the Danube is reflected into the current mentality of its inhabitants, in the context of a differentiated approach of the river associated with the cultural and ethnic diversity of the riparian countries.

Considering this aspect of the specificity of Danube perception throughout it, then applying the respective hypothesis to the city of Giurgiu, as a case study for the region of the Lower Danube in Romania, we have tested an atipical questionnaire set as basis for investigating the perception of various aspects of language, life, space, and natural landscape of this territory. Beyond the urban or rural labels (which are not quite accurate, but assumed by inhabitants by some inertial thinking) the Danube is perceived not only as a physical space, but also as a "living interior", mentally seen with the "peripheral" view - the one that does not focus directly on objects, but "instantly" records all the data of a complex reality. This reality includes not only the shape of the built-up Danube, its landscape and/or its functions / activities, but also its surroundings and even the associated feelings or generated by physical structures. 
Rezultatul cercetării verifică necesitatea de a înțelege mai bine Dunărea de jos atât ca purtătoare a unui specific local al locuirii (cu valențe tradiționaliste), dar și ca matrice cu valențe mai largi, la nivel regional/ european, ca manifestare a unor dorințe de inovație și de emancipare. "Mentalul" locuirii la Dunăre este alcătuit atât din elemente ce privesc percepția imediată și intens personalizată din viața cotidiană a oamenilor, cât și imagini sau date care se adresează memoriei, imaginației sau educației legate de Dunăre. Scopul principal a fost acela de a găsi caracterul specific și principalii indicatori ai "imaginii mentale" a Dunării pentru locuitorii actuali ai orașului Giurgiu, și totodată de a pregăti un model de cercetare a acestui aspect ca extrapolare pentru intregul teritoriul al Dunării. Am realizat această lucrare ca activitate de cercetare în cadrul proiectului DANUrB (http://www.interregdanube.eu/approved-projects/danurb), completarea altor studii asociate, de ex. studiul valorilor "ascunse" de patrimoniu local, studiul asupra potențialului turistic, sau al peisajul sonor al orașului în raport cu Dunărea.

Pentru a identifica modul în care se reflectă Dunărea în mentalitățile și comportamentele actuale ale locuitorilor săi din orașul Giurgiu, am aplicat un chestionar atipic ca bază a cercetării percepției diferitelor aspecte ale vieții, spațiului și peisajului natural aferente acestui teritoriu. Acest chestionar, așa cum a fost structurat și conceput de autor, dezvăluie diferențele de percepție ale fluviului Dunărea în acest oraș, dar și diferențele de ințelegere a unui limbaj voit abstractizat asupra unor aspecte spațiale ale prezenței fluviului în viața urbană. Obiectivele de cercetare suplimentare ale chestionarului vizează decriptarea imaginii tabu a "omului de la Dunăre", peisajul "verbalizator"
The result of the research verifies the need to better understand the Danube both as a carrier of a local dwelling specificity (with traditionalistic valences), but also as a matrix with valences of universality, as a manifestation of desires for innovation or correlation with other models. The "mental" of living on the Danube is made up of both elements that concern the immediate and intensely personalized perception of people's daily lives, as well as images or data that address memory, imagination or education related to the Danube. The main purpose was to find the specific character and main indicators of the "mental image" of the Danube for the current inhabitants of Giurgiu, and at the same time to prepare a research model of this aspect as extrapolation for the whole territory of the Danube. I performed this work as a research activity within the DANUrB project (http://www.interregdanube.eu/approved-projects/danurb), in addition to other associated studies, eg. the study of the "hidden" values of local heritage, the study of the tourist potential, or the sound landscape of the city in relation to the Danube.

To identify how the Danube is reflected in the current mentalities and behaviors of its inhabitants in the city of Giurgiu, we applied an atypical questionnaire as a basis for researching the perception of different aspects of life, space and natural landscape related to this territory. This questionnaire, as it is structured and conceived by the author, reveals findings on the perceived differences of the Danube River in this city, but also the differences in understanding an intentionally abstracted language, about several spatial aspects of the river's presence in urban life. Additional research objects of the questionnaire involve the decryption of the taboo image of the "Danube's Man", the 
(generat de cuvinte și de co-noțatiile acestora) și reprezentarea mentală a relației ipotetice dintre cele două așezări situate pe ambele maluri ale Dunării de Jos (orașele "gemene" Giurgiu și Ruse).

În principal, chestionarul utilizat este un material de 10 întrebări, dar pentru că limba induce uneori un mod de a răspunde prin cuvintele însele, pentru a ne conecta la aspectele vieții de zi cu zi sau a contextului mai intim, am completat textul cu imagini, logo-uri, desene schematice sau fotografii, luând în considerare acest lucru în spiritul a ceea ce a spus Merleau-Ponty: "Semnificația deplină a unei limbi nu este niciodată translatabilă la altul. Putem vorbi mai multe limbi, dar una dintre ele rămâne întotdeauna cea în care trăim" (Merleau-Ponty [1945] 1999, 136).

Numărul total de respondenți este de 70, dintre care $63 \%$ sunt actori locali (funcționari la primarie, angajati în instituții locale culturale sau administrative, profesori de școală generală sau liceu, dezvoltatori urbani, agenți imobiliari, oameni de afaceri, activişti sociali) și 37\% sunt studenți la arhitectură și planificare urbană sau peisagistică din UAUIM.

\section{Context}

Dunărea este un generator puternic și activ de modele (spațiale, sociale, culturale, mentale, comportamentale) care se reflectă mai ales în trăsături fizice și morale distincte ale locuitorilor săi. Geografia fizică foarte variată a României este corelată unor "tipare umane" la fel de bogat variate și, prin urmare, cu moduri specifice de viață, percepție, "construire, locuire, gândire" (Heidegger, "verbalizing" landscape (generated by words and their co-notation) and the mental representation of the hypothetical relationship between two settlements located on both sides of the Danube (the „twin cities” Giurgiu \& Ruse).

Mainly, the questionnaire used is a written material of 10 questions, but because the language sometimes induce a way of answering through the words themselves, to connecting to aspects of daily life or a more intimate context, we completed it with images, abstract logos, schematic drawings, or photos of different aspects of live, considering this in the spirit of what Merleau-Ponty said: "The full meaning of a language is never translatable to another. We may speak several languages, but one of them always remains the one in which we live" (Merleau-Ponty [1945] 1993, 136)

The total number of respondents is 70 , of which $63 \%$ are local stakeholders (town hall officials, employees in cultural institutions, school teachers, urban developers, real estate agents, businessmen, social activists) and $37 \%$ are students in architecture and urban or landscape planning of UAUIM.

\section{Background}

The Danube is a strong and active generator of patterns (spatial, social, cultural, mental, behavioural) that accumulate both physical as well as moral and behavioural traits of its inhabitants. The very varied physical geography of Romania is correlated with "rich human patterns" and, therefore, with specific ways of life, perception, "building, dwelling, thinking" (Heidegger, 1996). This 
1996). Această varietate antropo-culturală este legată în mod subtil de formele reliefului predominant în peisajul trăit: munte, mare, câmpie, deal, toate caracterizând diferite categorii de locuitori. Dacă însă în ceea ce privește cultura românească, "omul munților" sau "omul de la mare" se referă la modele foarte precise care implică caracteristici specifice ale spațiului de viață (de la tiparul satelor și al gospodariei, până la detaliile decorative ale caselor), modelul "omului de la Dunăre" nu este foarte clar. Astfel, chestionarul nostru vine din necesitatea de a investiga imaginea "omului de la Dunăre" în percepția sa uzuală, pornind de la faptul că prima referință a acestei expresii este a omului din Delta Dunării - spațiu mult mai bine reprezentat (și mai bine promovat) în mentalul colectiv și nu cel al teritoriului Dunării de Jos la care face referire studiul. Totodată, pornim de la câteva atribute stereotipizate în limbajul și percepția curente, care asociază trăsăturile apei Dunării cu caracterul generic al omului dunărean: priceput, inteligent și turbulent (neinhibat, imprevizibil). Însă acestea sunt etichete născute din dorința de a simplifica un conținut cultural cvasinecunoscut. Cum este percepută ființa umană care trăiește la Dunăre? Ce este în mintea lui/ei când este întrebat/ă unde locuiește? - am putea chestiona, având în vedere cuvintele lui Merleau-Ponty, care a spus, comentând filozofia lui Descartes: "Sufletul nu este în corp ca un pilot în nava lui, este complet amestecat cu corpul său. Corpul, la rândul său, este complet animat și funcțiile sale contribuie la percepția obiectelor " (Merleau-Ponty apud Fischer 1969, 83).

Intenționăm prin acest studiu să verificăm empiric cum se suprapune imaginea mentală a oamenilor din regiunea Dunării de Jos din România cu anthropo-cultural variety is in subtle way related to the forms of relief prevalent in the lived landscape: mountain, sea, plain, hill, all of them characterizing different categories of inhabitants. But, as for the Romanian culture, the "man of mountains", or the "man from the sea" refers to very precise patterns which involves a sum of characteristics of the specific living space, for the Danube, the pattern of the man living on Lower Danube is not very clear. So, our questionnaire comes also from the necessity to investigate on the image of the "Danube's man" - a not very well defined one in the common understanding, proved by the fact that the first reference of this expression is of the Danube Delta a much better represented (and better promoted) space in the collective imaginary - and not of the Lower Danube territory. At the same time, we start from some stereotyped attributes in the current language and perception, which associates the features of Danube water with the generic nature of the Danube man: skilled, intelligent, turbulent (uninhibited, unpredictable). But these are labels born out of the desire to simplify a quasi-unknown cultural content. How does the Danube human being perceive him/herself? What is in his/her mind when asked about where he/she lives? - we could ask, keeping in mind the words of Merleau-Ponty, who said, commenting on Descartes's philosophy: "The soul is not in the body like a pilot in his ship; it is wholly intermingled with the body. The body, in turn, is wholly animated and its functions contribute to the perception of objects" (Fischer 1969, 83).

We intend by this study to check how the mental image of Danube people overlaps with the physical and spatial landscape features. For this, we also 
caracteristicile peisajului fizic și spațial. Pentru aceasta, considerăm relevant și discursul despre peisajul "verbalizat" (practicat), mai mult decât producția teoretică și imagistică bazate pe acesta.

Spațiul mental - spațiu al reducțiilor, al forței și al represiunii, al manipulării și co-optării, distrugătorul naturii și al corpului - nu este în măsură să neutralizeze dușmanul în interiorul porților sale. Departe de asta: încurajează de fapt acest dușman, de fapt ajută la reînvierea lui. Ceea ce ne duce mult mai departe decât contradicțiile adesea menționate între estetică și raționalism. (Lefebvre [1974] 1991, 157).

Dunărea este unul dintre acele teritorii care, în încercarea de a se defini ca brand, prin valorile sale unice, dincolo de caracteristicile fizice și geografice diferențiatoare, întâlnește masa imensă a diversității socio-culturale și lingvistice, istoric înrădăcinată: o adevărată indestructibilă barieră pentru un concept bazat pe uniformitate. Dar limbajul, la fel ca lumina, poate fi descompus în fascicule, poate fi secționat până la rădăcinile sale, oferind astfel o interpretare copleșitoare care dovedește că există o dialectică în toate limbile - o unitate în toate contradicțiile evidente. În lucrarea "Devenirea Peisajului", am găsit rațiunile și am dezvăluit canalele perceptuale ale evoluției peisajului (Stan 2012), descoperind, ajutați de Deleuze\&Guattari, că orice peisaj este, mai presus de toate, o imagine mentală, o construcție complexă, ramificată, intermitentă și capricioasă (Deleuze\&Guattari 1980). Și că spațiul care găzduiește sau stă la originea unui peisaj este instalat periferic în acest construct, iar informațiile adiacente vin pe calea retenției mnemonice, a viselor sau chiar a clișeelor culturale.

După Lefebvre (1991 [1974]), putem găsi consider relevant the discourse about the "verbalizing" (practicing) landscape, more than the theoretical and imagistic production based on it.

\begin{abstract}
Mental space - the space of reductions, of force and repression, of manipulation and co-optation, the destroyer of nature and of the body - is quite unable to neutralize the enemy within its gates. Far from it: it actually encourages that enemy, actually helps to revive it. Which takes us far further than the often - mentioned contradictions between aesthetics and rationalism (Lefebvre [1974]1991, 157).
\end{abstract}

The Danube is one of those territories that, in the attempt to define itself as a brand, by its unique values, beyond its physical and geographic differentiating features, meets the huge mass of socio-cultural and linguistic diversity, historically rooted: a real indestructible barrier for a concept based on uniformity. But the language, just as the light, can often be de-compounded into beams, can be split up to its roots, and so it offers the look of an overwhelming interpretation that prove that there is a dialectic in any language - a unity in all obvious contradictions. In the work "The Landscape Becoming", we find the rationales and reveal the perceptual channels of the landscape evolution (Stan 2012), and we discovered, helped by Deleuze \& Guattari, that any landscape is, above all, a mental picture, a complex, branched, intermittent and whimsical construct (Deleuze \& Guattari 1980). And that the space which hosts or stands at the origin of a landscape is peripherally installed in this construct, as adjacent information coming through the path of mnemonic retention, dream, or even cultural clichés.

Following Lefebvre ([1991 1974]), we can find the 
capacitatea de producție și reproiectare a spațiului (dunărean) corelată cu capacitatea practic nelimitată a limbii vorbite și practicate de oameni, de a se îmbogăți, de a se transfigura, de a ieși din propriile rețete și reprezentări stereotipe. Poezia - și mai ales poezia contemporană, mai adaptată presiunilor societale actuale - este cea care consolidează limbajul și îi depășește limitele, iar acest fapt, dacă ajunge să fie conștientizat de locuitori, le stimulează foarte mult capacitatea de a depăși barierele din planul mental al propriilor reprezentări ale vieții, ale prezentului și ale viitorului. Din acest motiv, am implicat poezia în studiul nostru, chiar de la început, așa cum Lefebvre a făcut-o în motto-ul faimoasei sale cărți "The Production of Space", cu textul lui Octavio Paz ("Envoi"):

Închis între patru ziduri / (spre nord, cristalul necunoașterii / un peisaj care trebuie inventat / spre sud, memoria reflexivă / spre est, oglinda / spre Vest, piatra și cântecul tăcerii) / am scris un mesaj, dar nu am primit niciun răspuns. (Octavio Paz apud Lefebvre 1991 [1974], 3)

Dacă acest obiectiv ar fi prea ambițios pentru acest studiu în această etapă, ne-am rezumat la cele mai frecvente scheme mentale, la reprezentări simplificate ale spațiului Dunării și la imaginile dominante ale vieții urbane/rurale din acest teritoriu și prin acestea ajungem să evidențiem principalele indicii ale cunoașterii mentale a Dunării de Jos în România. Din acest punct pornind, studiul poate continua până la amplitudinea unei imagini complete care ar utiliza într-o maniera mai profundă poezia ca instrument de sondare și "manipulare" complexă psiho-lingvistică cu scopul de a releva mentalul uman în relație cu modul de apropriere a spațiului locuit. production and re-production capacity of the (Danubian) space correlated to the practically limitless capacity of any human practiced language, to self-enrich, to transfigure, to get out of their own grids and common representations. Poetry - and especially contemporary poetry, more adapted to the actual societal pressures - is the one that strengthens the language and exceeds its limits, and this fact, if arrives to be known by the inhabitants, highly stimulates the people ability to surpass the limits in the mental plan of their own representations of life, of present and future within this territory. For this reason we immerse poetry in our study, just from the beginning, as Lefebvre did just in the motto of his famous book "The Production of Space", with this texts from Octavio Paz ( "Envoi"):

Imprisoned by four walls/ (to the North, the crystal of non-knowledge/ a landscape to be invented/ to the South, reflective memory/ to the East, the mirror/ to the West, stone and the song of silence)/ I wrote message, but received no reply. (Octavio Paz apud Lefebvre 1991 [1974], 3).

If this would be too ambitious objective for this study at this stage, we framed to the most frequent mental schemes, the simplified space representations, the dominant images of Lower Danube's urban/ rural life, and through these, we aim to point out the main markers of mental knowledge of this region in Romania. From this point on, the study can continue to the fullness of a complete image that would use poetry in a deeper way as a sound instrument and complex "manipulation" psycho-linguistic in order to reveal the human mind in relation to the approach of living space. 


\section{Structura chestionarului. Conținut și rezultate}

Modul de interogare a fost ales astfel încât să nu inducă prejudecăți, dar în același timp să provoace latura interioară a percepției și comportamentului populației, apoi să coreleze răspunsurile numeric dominante obținute de la respondenți cu explicații și interpretări calitative, luând în considerare observațiile personale și detaliile vieții urbane din Giurgiu.

\section{Conținutul chestionarului}

Următoarele întrebări au fost adresate oamenilor din Giurgiu:

1) Care animal este cel mai bine asociat cu Dunărea, în spațiul în care locuiți? (alegeri: cal / oaie / pui / pește/ maimuță / șarpe / vacă / specificați altele);

2) Ce fel de copac puteți asocia cel mai bine spațiului Dunării? (opțiuni: stejar / plop / castan / salcie/ castan/ specificați alte);

3) Ce fel de locuință credeți că este cea mai potrivită pentru Dunăre? (alegeri: casă cu parter / casă cu un etaj /casa cu pridvor / casă cu balcoane / casă cu 24 etaje / bloc de apartamente / specificați altele)

4) Marcați 3 dintre eventualele riscuri legate de Dunăre, de care vă temeți cel mai mult? (opțiuni: cutremur / alunecare de teren / inundații / tornadă / îngheț / foc / altele)

5). Care dintre următoarele verbe vă par potrivite pentru a descrie Dunărea? (3 maxim / alegeri: a fi /

\section{The structure of questionnaire. Content and results}

The way of questioning was chosen so as not to induce pre-judgings, but at the same time to capture the inner side of the people perception and behaviour related to the space where they live, then correlating the numerical dominant answers obtained with qualitative explanations and interpretation, taking into account personal observations and details of urban life in various cities on Danube.

The questionaire content

The following questions have been addressed to people from Giugiu (during 2018-2019 DANUrB project period):

1) Which animal is best associated with the Danube, within the space where you live? (choices: Horse/ Sheep/ Hen/ Fish/ Donkey/ Snake/ Cow/ specify other);

2) What kind of tree can you best associate to the Danube? (choices: Oak/ Poplar/Chestnut/ Willow/Ash /specify other);

3) What kind of residential house do you think is the most suitable to Danube? (choices: ground floor house/ one floor house/ house with porch/ house with balconies/ house with 2-4 floors/ block of apartments/specify other)

4) Mark 3 of the eventual risks related to the Danube which most fear you? (choices: earthquake/ landslide/ flood/ tornado/ frost/ fire/ other)

5). Which of the following verbs seem most suitable for describing the Danube? (3 maximum/ choices: to 
a trece / a mânca / a curge / a lucra / a pleca / specificați altele).

6) Care din următoarele atribute pare a fi cel mai potrivit pentru a descrie Dunărea? (Maxim 3 / opțiuni: clar / curajos / sărac / bogat / lung / vechi / specificați altul)

7) Care din următoarele siluete descrie cel mai bine orașul tău văzut de pe celălalt mal al Dunării? (alege una) be/ to pass/ to eat/ to flow/ to work/to leave/specify other)

6) Which of the following atributes seem most suitable for describing the Danube? (3 maximum/ choices: clear/ brave/ poor/ rich/long/ old/ specify other)

7) Which of the following sillhouette best describes your city seen form the other shore of the Danube? (pick one)

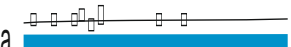

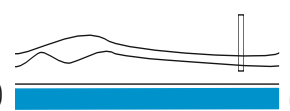

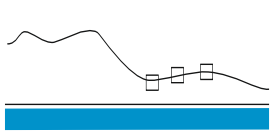

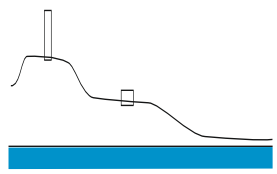

8) Care dintre următoarele scheme conceptuale găsiți că este cea mai potrivită pentru relația dintre orașul dvs. și orașul/ orașele (bulinele) pe Dunăre (linia)? (alege una)
8) Which of the following conceptual schemes do you find the most suitable for the relationship of your city with the city/ cities (the dots) over the Danube (the line)? (pick one)

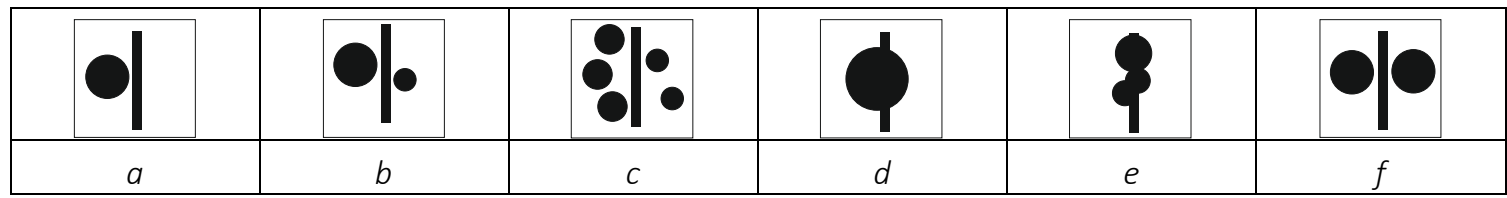

9) Care dintre următoarele imagini vă conectează mai bine la specificul vieții în apropierea Dunării? (alege una)
9) Which of the following pictures connects you better with the sens of living near Danube? (pick one)

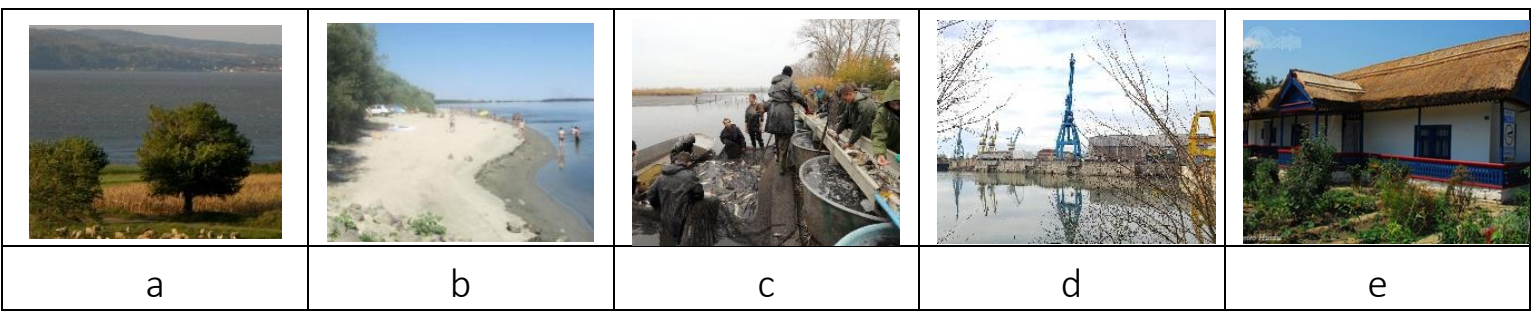




\section{Rezultatele chestionarului}

Un procent de $80 \%$ dintre respondenți au asociat Dunărea unui peisaj în care se regăsec elementele tradiționale, puternic simbolice ale spațiului dunărean românesc, în special ale celui de tip rural sau cu un grad redus de urbanizare. Astfel, animalul asociat Dunării de respondenți a fost calul (88\%) și într-o mai mică măsură peștele (12\%). Procentul mic al celor care consideră peștele ca fiind reprezentativ pentru spațiul urban dunărean se poate interpreta ca o recunoaștere a faptului că atât pescuitul ca activitate, cât și comerțul cu pește și prezența sa în gastronomia locală actuală este una destul de redusă (și necesită îmbunătățiri).

Arborele considerat că se potrivește cel mai bine Dunării de jos a fost stejarul (76\% din respondenți) iar restul de $14 \%$ au considerat că salcia este arborele reprezentativ al acestui teritoriu. Aceste opțiuni indică forța cu care arhetipurile culturale, unele sacralizatoare, sunt adânc înmagazinate în subconștientul colectiv. Calul, cum bine știm, are în cultura și civilizația populare din România, un puternic caracter mitic șio funcție magică şiceremonială. Conform mai multor cercetări în acest domeniu, locuitorii spațiilor rurale sau semiurbane din întregul teritoriul românesc, nu doar cel dunărean, consideră calul ca fiind "cel mai frumos, mai nobil şi mai deştept dintre toate animalele" (Dobre 2016, 16). Imaginarul colectiv asociază calului puteri supranaturale, care se regăsesc plenar și în literatura populară - în basme precum "Tinerețe fără bătrânețe și viață fără de moarte"și multe altele. Calul este pentru om un călăuzitor în toate întreprinderile sale, iar această trăsătură este exprimată prin proverbe precum: „Voinicul fără cal/E ca peştele pe mal",
The questionaire results

Around $80 \%$ of the respondents have associated the Danube with a landscape where are found the traditional, strongly symbolic elements of the entire Romanian Danube area, especially for the rural settlements. Thus, the respondents associated to Danube the horse (88\%), and to a lesser extent, the fish (12\%). The small percentage of those who consider the fish to be representative of Danube urban life can be interpreted as a recognition that both fishing as activity, the fish as trade and its presence in the local actual gastronomy is quite small (and deserves improvements).

The tree considered to best fit the Danube landscape is the oak (76\% of the respondents) and the rest of $14 \%$ considered that the willow is the representative tree of this territory. These options indicate the force with which the sacramental cultural archetypes are deeply stored in the collective subconscious. The horse, as we know well, has a strong mythical character and a magical and ceremonial function within the Romanian culture and civilization. According to several researches in this area, the inhabitants of rural or semi-urban spaces in the entire Romanian territory consider the horse to be "the most beautiful, noble and smarter of all animals" (Dobre 2016, 16). The collective imaginary gives supernatural powers to the horse, which are extensively found in folk literature - in fairy tales such as "Tinerețe fără bătrânețe și viață fără de moarte" ("Youth without old age and life without death"- trad.n.) and many others. From ancient times, the horse was a guide for man in all its businesses, and this trait is expressed by Romanian proverbs such as „Voinicul fără cal/E ca 
reflectând prin aceasta și faptul că este un simbol mai prezent în conștiința masculină decât în cea feminină.

La întrebarea 2, respondenții au arătat o preferință pentru stejar în locul salciei (mai potrivită pentru tipul bioclimatic al Dunării). Acest răspuns se poate interpreta fie în sensul că referința s-a făcut la un simbol de marcă superioară, valabil pe plan național (stejarul ca simbol al permanenței poporului român, a fost intens utilizat ca atare în perioada comunistă), fie în sensul referinței la un reper local - la plaja, ștrandul și tabăra "Stejarul", loc public din Giurgiu, pe malul Dunării, frecventat în număr mare de localnici pe timpul verii.

Pentru întrebarea numărul 3, tipul de locuință cel mai potrivit Dunării a fost considerat de respondenți (98\%) a fi casa cu prispă, confirmând tiparul tradițional de locuire al întregului spațiu dunărean, inclusiv al Deltei Dunării și dovedind o mică deschidere către alte forme, mai actuale de locuire urbană. Acesta este cumva un aspect paradoxal, pentru că vine în contradicție cu tendința actuală care se remarcă pe piața imobiliară, de a promova mai cu seama locuințele de tip apartament în blocuri cu înălțimi medii spre mari $(\mathrm{P}+4-\mathrm{P}+10)$.

Dintre riscurile legate de Dunăre care inspiră cel mai mult teamă (cutremur, alunecare de teren, inundație, tornadă, îngheț, incendiu) respondenții au ales în majoritate (85\%) inundațiile + cutremur + îngheț sau, în 7\% din cazuri, au adăugat seceta, confirmând o corectă percepție asupra caracterului instabil climatic și cu extreme peştele pe mal" ("The young man without horse / is like the fish on a shore"- trad.n.). Thus, this proverb and others similar are reflecting that the horse is a more present symbol in the male consciousness, than in feminine ones.

At the question 2, the respondents show the preference for the oak instead of the willow (more appropriate for the bioclimatic type of Danube). This response can be interpreted either in the sense that the reference is made to a upper mark symbol, nationally valid (the oak as a symbol of the permanence of the Romanian people within the territory, used like symbol during communist times), or as a reference to a ultra- local landmark - the beach and the camp named "Stejarul", a recreational public place in Giurgiu- city, on Danube shore, frequented by a large number of locals during summer time.

For the question number 3 , the most suitable type of house on Danube was considered by the respondents (98\%) to be the house with porch (casa cu prispă), confirming the traditional dwelling pattern of the entire Danube area, and proving a quite small opening to other forms of modern urban dwelling. This is somehow a paradox, because is coming in the contradiction with the current trend on the local and regional real estate market, which largely promotes residential developments for block of apartments of 4-10 stores.

Of the risks that most of the fears related to the Danube (question 4), $85 \%$ of the respondents have chosen flood and earthquake, and a percent of $7 \%$ add as choice the drought as expectable risk on Danube territory, confirming a correct perception of the unstable climatic character and the hydrological extremes of the territory during last decades. 
hidrologice al teritoriului pe care îl locuiesc.

Verbele considerate de respondenți ca fiind cele mai potrivite/ des întâlnite pentru descrierea Dunării au fost: ,"a trece”, , ,a curge”. Dacă 100\% au bifat cele 2 verbe cumva implicite sau direct legate de caracterul natural al Dunării, cel de-al treilea verb ales a fost în procent de $60 \%$ verbul "a fi", 25\% "a sta" și adaugat de respondenți - 15\% verbul "a lipsi". Aceste opțiuni ne dau un indicator asupra relației locuitorilor din Giurgiu cu natura trecătoare a apei Dunării, pentru cei mai mulți acest caracter fiind unul existențial. De asemenea, putem interpreta această alegere în legătură cu aspectul demografic al emigrației unei populații mari din orașe ca Giurgiu, din cauza lipsei de oportunități de angajare și a dezvoltării personale. Fenomenul de contracție se întâlnește în multe orașe ex-industriale românești care și-au pierdut activitatea productivă după 1990 și, prin urmare, au intrat într-un declin social și demografic, corelat cu o "periferizare" interioară a tuturor condițiilor vieții urbane și a încrederii comunității (Stan 2019, 56).

În mod oarecum surprinzător, atributele care au fost desemnate ca fiind cele mai potrivite pentru descrierea Dunării (întrebarea 6), au fost nu cele indicate în lista chestionarului, ci au fost propuse altele, precum: "tulbure", "neliniștit", "impetuos". Din cele indicate în listă, a fost menționat, într-un procent relativ mic (15\%) atributul "lung". Acest fapt reflectă încă o dată modul personal, existențial, puternic legat de tradiție și în același timp plin de responsabilitate a locuitorilor de a se raporta la caracterul Dunării în viața cotidiană.

Silueta care descrie cel mai bine orașul Giurgiu văzut de pe celălalt mal al Dunării (întrebarea 7) a fost
The verbs considered by the respondents to be the most appropriate for describing the Danube were: "passing", "flowing". If $100 \%$ checked the two verbs implicitly or directly related to the natural character of the Danube, the third verb picked out by the 60\% of respondents was "to be", "to stay" (25\%) and added by themselves "to miss" (15\%). These options give us an indication of the relationship of the inhabitants of Giurgiu with the passing nature of the Danube water, for most of them, this character being an existential one. Also, we can interpret this choice related to the demographic aspect of immigration of a large amount of population from the cities as Giurgiu, because of the lack of job opportunities and personal development. The shrinkage phenomenon is encounter in many Romanian ex- industrial cities which lost their productive activity after 1990, and due to this, entered in a social and demographic decline, correlated to a inner "peripherization" of all states of urban life and of the community trust (Stan 2019, 56).

Surprisingly, the attributes that have been designated as best suited for describing the Danube (question 6) were not those listed in the questionnaire, but others have been proposed, such as: "troubled", "restless", "impetuous". Of the listed list, the "long" attribute was mentioned in a relatively small percentage (15\%). This fact again reflects the personal, existential way, strongly related to the tradition and, at the same time, the responsibility of the locals in the relationship with the Danube character, in everyday life.

The silhouette which best describes the city of Giurgiu seen form the other shore of the Danube 
aleasă ca fiind "a" (78\%) și într-un procent relativ apropiat (65\%) "b". Alegerea siluetei "a" ca reprezentativă pentru Giurgiu este legată de percepția corectă a locuitorilor cu privire la lipsa unor repere spațiale importante în frontul orașului catre apă și a reliefului său plat. Silueta "b" reflectă conștientizarea că există totuși repere spațiale existente la scara orașului, dar repere singulare / izolate, și provenind din timpurile istorice anterioare. Putem presupune că acest reper singular ales în schema "b" este proiecția mentală a Turnului cu Ceas (mult timp unul dintre cele mai înalte edificii din Giurgiu) sau, în cheie post-industrială, posibil a fi macaralele de la șantierul naval, care încă mai domină malul Dunarii la Giurgiu.

Întrebarea 8 este referitoare la reprezentarea mentală a relației ipotetice dintre două așezări / orașe situate pe ambele maluri ale Dunării, și cel mai optat raspuns a fost schema simetrică și echilibrată (fig. "f") care vizează în mod ideal cea mai bună formă de cooperare, de pe poziții egale. În funcție de pregătirea / studiul respondenților, am observat o variație semnificativă, ceea ce înseamnă că cei cu studii spațiale (arhitectură, urbanism, peisaj, arte și dezvoltare spațială) preferă scheme mai complexe (figurile "b", "c ,"e"), reflectând o cooperare bazată pe asumarea diversității și a diferențelor dintre orașele situate pe râu. Aceste alegeri pot fi, de asemenea, interpretate ca efect al lipsei educației vizuale și a capacității de a face corelații între reprezentările grafice și realitatea / viziunile care pot fi reprezentate pentru dezvoltarea unui anumit teritoriu. Aceasta este, de asemenea, o concluzie parțială la care și alți cercetători din echipa DANUrB au ajuns prin studii similare, dar cu instrumente ușor diferite. (question 7) was pick as being no. "a" (78\%) and in a quite close percentage (65\%) no. "b". The choice of silhouette "a" as a representative of Giurgiu is related to the correct inhabitants' perception on the lack of important spatial landmarks in the front of the city and its flat relief. The silhouette " $b$ " reflects the awareness that there are still existing spatial landmarks at the city's scale, but as singular/isolated landmarks, and coming from earlier historical times. We can presume that this singular landmark is the mental projection of the Clock Tower (long time one of the tallest edifices in Giurgiu) or, in post-industrial key, possibly to be the shipyard cranes, which still dominate Giurgiu's waterfront.

The question 8 related to the mental representation of the hypothetical relationship between two settlements/cities located on both sides of Danube, the most opted one was the symmetrical and balanced figure (fig." $f^{\prime \prime}$ ) ideally targeting the best form of cooperation, on/by equal positions. Depending on the respondents' training/studies, they have noticed a significant variation, meaning that those with spatial studies (architecture, urbanism, landscape, arts, and spatial development) preferred more complex schemes (fig." b", "c $c$,,"e"), reflecting a cooperation based on the assumption of diversity and differences between cities located on the river. These choices may also be interpreted as a lack of visual education and of the ability to make correlations between graphical representations and reality/ visions that can be plotted for a specific territory. This is also a partial conclusion which other researchers from DANUrB team have arrived through similar studies but with slightly different tools. 
Dacă înțelegerea spațiului de viață este importantă pentru dezvoltarea științelor sociale, ea este de asemenea fundamentală în procesul de luare a deciziilor. Pentru a implementa politici sau programe care ar fi compatibile cu modurile de trai ale locuitorilor, este necesar să aruncăm mai înainte o lumină asupra modului în care teritoriul este de fapt însușit de ei, să înțeleagă care sunt principalele sale trăsături, granițele și miturile și să analizăm modul în care se simte simbolic ca un teritoriu stabilirea unei identități comune. Oferind o imagine a modului în care teritoriile de-a lungul Dunării sunt exprimate și trăite în realitatea interioară a locuitorilor lor - și anume spațiul trăit - sunt deosebit de valoroase pentru factorii de decizie, părțile interesate locale si planificatorii urbani. Astfel, luarea în serios a reprezentărilor sociale și a imaginarului este un pas cheie în tranziția spre un model de dezvoltare durabilă, în măsura în care acesta din urmă trebuie să ia în considerare aproprierea populară a teritoriilor. (Anranter et all 2015, 12).

La întrebarea 9, imaginea aleasă în cea mai mare masură (84\% dintre respondenți), considerată a reprezenta în cel mai bun mod sensul de a trăi în apropierea Dunării, este "b" - imaginea plajei. Ținând cont de faptul că această imagine nu este din Giurgiu, ci din alt oraș (nu departe) de pe Dunăre (Corabia) și că la Giurgiu nu există un loc similar (plajă nisipoasă) din cauza stării naturale a fluviului Dunărea, putem să interpretăm acest răspuns ca fiind "un lucru dorit", o reprezentare mentală a ceea ce Dunărea ar trebui să ofere locuitorilor săi, pe lângă condițiile elementare de a trăi și de a lucra.
If understanding the lived space is important for social sciences' development, it is also fundamental in the decision-making process. In order to implement policies or programs that would be compatible with inhabitants' ways of living, it is necessary to previously shed light on the way the territory is actually being appropriated by them, to understand what are its key features, its boundaries, its myths, and to consider the way it is symbolically being reified as a territory - establishing a common identity. Offering a view of the way territories along the Danube are expressed and lived in their dwellers' inner reality - namely the lived space - is particularly valuable for decision makers, local stakeholders and urban planners. Thus, taking social representations and imaginary seriously is a key step in the transition toward a sustainable development model, inasmuch as the latter has to take the popular appropriation of territories in account. (Anranter et all 2015, 12).

At the question 9, the most picked up image (84\% of the respondents), considered to represent in the best way the sense of living near Danube, was no. "b"- the image of the beach. Taking in consideration that this image is not from Giurgiu, but from another (not far away) Romanian city on Danube (Corabia) and that at Giurgiu there is not a similar place (sandy beach), because of the natural condition of Danube flows, we can interpret this answer as a "wishful thing", a mental representation of what Danube should offer to its inhabitants, besides the elementary condition for living and working. 


\section{Concluzii}

Rezultatele chestionarului completat de părțile interesate din Giurgiu și de studenții români implicați în proiectele DANUrB au arătat că Dunărea este strâns legată de viața lor, iar interesul pentru dezvoltarea orașului este unul real și profund, adesea plin de imaginație și pozitivism.

De asemenea, rezultatele au arătat că Dunărea este strâns legată de spațiul de viață, iar interesul pentru dezvoltarea orașului este unul nu lipsit de viziune, dar limitat la anumite scheme stereotipe. Majoritatea răspunsurilor cu referire la aspecte concrete ale vieții au ieșit din sfera convenționalului, probând potențialul de îmbunătățire a imaginii mentale a Dunării pentru locuitorii acestor spații. Acest lucru poate fi conceput ca un punct de plecare pentru o viitoare strategie care să vizeze dezvoltarea în jurul problemelor și modelelor interioare ale vieții lor.

Limitarile cercetării sunt totuși induse de numărul restrans de respondenți dictat de condițiile desfașurării studiului în cadrul proiectului mai sus amintit, iar interpretarile sunt în mod asumat personale și posibil subiective.

Ca o extensie a acestui studiu, considerăm că ne putem referi la problematica practicării limbajului cu instrumente neconvenționale - precum poezia modernă - pentru ca oamenii să înțeleagă faptul că spațiul (de) locuit - spațiul urban, malul Dunării, plaja, parcul etc. - poate fi asumat, așa cum este asumată (căci practicată) limba de zi cu zi, cu toate posibilitățile sale infinite de transformare. Din acest scenariu aplicat rezultă că poezia ar putea fi concepută ca un instrument inovativ pentru a

\section{Conclusions}

The results of the questionnaire completed by the stakeholders in Giurgiu and by the Romanian students involved in the DANUrB projects revealed that Danube is intimately linked to their life, and the interest in the city development is a real and profound one, often full of imagination and positivism.

Also, the results revealed that Danube is intimately linked to the space of life, and the interest in the city development is a visionary one, but limited to certain stereotyped schemes. Most of the answers regarding concrete aspects of life have come out of the conventional sphere, proving the potential of improving the mental image of the Danube for the inhabitants of these areas. This can be conceived as a starting point for a future strategy aimed at developing around the problems and internal patterns of their lives.

However, the limitations of the research are induced by the limited number of respondents dictated by the conditions of the study in the aforementioned project, and the interpretations are assumed to be personal and possibly subjective.

As an extension of this study, we consider that we can refer to the problem of practicing language with unconventional instruments - such as modern poetry - so that people understand that the living space - the urban space, the banks of the Danube, the beach, the park, etc. - can be all assumed, as it is "inserted "(because it is practiced) in the everyday language, with all its infinite possibilities of transformation. From this applied scenario it follows that the poetry could be envisioned as a tool for 
"provoca" capacitatea de abstractizare a oamenilor, folosind limbajul ne-denotativ, metaforic și abstractizat, scriptic și grafic. Asumarea și depașirea diverselor tipare - lingvistice, spațiale, culturale, comportamentale - poate fi concepută ca parte dintr-o strategie de stimulare a locuitorilor pentru a vedea dincolo de stereotipuri și a-și angaja energia pentru a face un viitor mai bun (Kaufmann, Ravalet 2019, 195). determine the people capacity of abstractization using written and graphic language - in order to induce them the liberty in assuming various patterns - spatial, cultural, behavioual- and thus, to stimulate them to see beyond the stereotypes, and to engage their enery into making a better future (Kaufmann, Ravalet 2019, 195).

\section{Referinţe/ References}

Merleau-Ponty. M. [1945] 1999. Phénomenologie de la perception, traducere de llieș Câmpeanu, Goergiana Vătăjelu. Oradea: Aion.

Fischer, A.I. (ed.) (1969). The essential writings of Merleau-Ponty. San Diego: Harcourt, Brace \& World. Heidegger. M. (1996) [1945]. Originea operei de artă, trad. de Thomas Kleininger și Gabriel Liiceanu, București: Humanitas.

Deleuze, G., Guattari, F. (1980). Mille plateaux: capitalisme et schizophrénie. Paris: Éditions de Minuit Stan, A. (2012). Devenirea peisajului. Bucuresti: Ed. Ion Mincu. Lefebvre, H. [1974] (1991). The production of Space. Oxford: Basil Blackwell.

Stan, A. (2019). Good places in shrinking cities. Alternative approach of urban peripheries. In Păun- Constantinescu, I. (ed.), Shrinking cities of Romania, responses and interventions, Bucharest- Berlin: MNAC and DOM publishers.

Dobre, A. (2016). Etnologia poporului roman, Bucuresti: Ed. Etnologica.

Anranter, M; Dumreicher, H.; Kolb, Bettina and Levine, R.S (2015). Exploring spaces of possibilities for arts, culture, public space, and civil society.In The International Journal of Social, Political and Community Agendas in the Arts, 10(3). Kaufmann, V. Ravalet, E. (2019). L'urbanisme par les modes de vie. Outils d'analyse pour un aménagement durable. Paris: Metise Presses.

www.interreg-danube.eu/approved-projects/danurb, accesat la 11.07.2019 